Світлана Галаур

ORCID: https://orcid.org/0000-0002-9333-3052

Ірина Якубенко

ORCID: https://orcid.org/0000-0003-3907-9249

DOI 10.31558/1815-3070.2020.40.2.4

УДК $81 ’ 42-028.61$

\title{
ХУДОЖНІЙ ПОЛІТИЧНИЙ ДИСКУРС І ЙОГО РЕГУЛЯТИВНИЙ ВПЛИВ
}

\begin{abstract}
Порушено проблему політичного різновиду дискурсу, який інтенсивно завойовує позиції пріоритетного в житті суспільства й навіть репрезентує себе в художній літературі. Розглянуто регулятивність як особливий вплив у художньому політичному дискурсі. Установлено регулятивні засоби, щуо стимулюють мовно-мисленнєву діяльність читача та стають основою для майбутнього моделювання концептів. Особливу увагу звернено на суспільнополітичну лексику, дисфемізми, суспільно-політичні метафори, антитезу.
\end{abstract}

Ключові слова: дискурс, художній політичний дискурс, категорія впливу, регулятивність, регулятивні засоби художнього політичного дискурсу.

Поняття дискурсу як складного комунікативного явища є домінантним у різних сферах сучасної лінгвістики. 3-поміж багатьох дискурсних проблем мовознавство розв'язує і ту, що демонструє соціальну варіативність дискурсу, один iз різновидів якого - політичний - інтенсивно завойовує позиції пріоритетного в житті суспільства, ба навіть репрезентує себе в художній літературі.

Політичний дискурс загалом достатньо студійований у світовому мовознавстві (О. Баранов, Р. Барт, Ю. Габермас, Т. ван Дейк, Г. Почепцов, Н. Фер клоу, О. Шейгал). Особливої уваги нині потребують його різновиди, 3-поміж них і зактивізований в останні роки художній політичний дискурс. У вітчизняних наукових джерелах про нього лише спорадично згадують (М. Голіченко, Т. Шарова, Д. Шевчук та інші), спроб установити його структурно-функційні параметри не зафіксовано. Для усвідомлення специфіки цього різновиду політичного дискурсу важливим видається дослідження в ньому однієї із центральних категорій - впливу, що вибудовує «соціальність» комунікації, розгорненої як пер едбачувана реакція на виклик адресанта.

Метою дослідження $є$ опис регулятивності як особливого впливу в худо жньому політичному дискурсі. Для досягнення поставленої мети потрібно розв'язати такі конкретні завдання: описати регулятивний вплив художнього політичного дискурсу, порівняти його з маніпулятивним впливом політичного дискурсу; виявити конкретні регулятивні засоби в сучасному художньому політичному дискурсі. Об'сктом дослідження є художній політичний дискурс, а предметом засоби його впливу на читача. Фактичним матеріалом послугували пр иклади із сучасної української художньої літератури політичного змісту. Дослідження грунтується на сучасних методах аналізу художніх текстів - лінгвопоетичній iнmерпретаціï, що передбачає тлумачення змісту тексту на тлі системно-семан-

(C) Галаур C., Якубенко I., 2020 
тичних відношень різнорівневих мовних одиниць, регулятивному структуруванні, зорієнтованому на спостереження за стимуляторами різних комунікативних ефектів, інформаційно-змістовому, спрямованому на аналіз змістового розгортання тексту. Науковою новизною дослідження є аналіз одного $з$ типів політичного дискурсу, що через свою периферійність не став предметом цілеспр я мованої уваги лінгвістів. Теоретичною цінністю роботи може стати уточнення класифікаційних параметрів політичного дискурсу, практичною-застосування іï результатів в освітній практиці для громадянського виховання молоді засобами художньої літератури.

Важливою категорією як художнього, так і політичного дискурсів є категорія впливу. Вплив здійснюється за способом коректного добору арсеналу м ентальних одиниць, їхнього вдалого стилістичного оформлення. Вплив пов' язаний із реалізацією комунікативної інтенції - «різновиду ментальної р епрезентації людини, що становить намір мовця донести до адресата певну спрямованість своєї свідомості на об'єкти та стани речей зовнішнього світу й у такий спосіб вплинути на нього» (Безугла 95).

Категорія впливу має дві субкатегорії - пер еконання (вплив на раціональну сферу свідомості реципієнта) та навіювання, або сугестії (вплив на підсвідомість, почуття й емоції адресата). І політичний, і художній тексти активно використовують другу субкатегорію, але по-різному.

Для політичних текстів характерний прихований психологічний вплив, «цілі якого < ..> маскуються під цілі відкритої взаємодії, і адресат пр иймає р ішення (чи виконує дію), заплановане ініціатором впливу» (Гребінь 84). Художні тексти частіше апелюють до відкритого психологічного впливу, мета якого не приховується.

Прихований вплив найчастіше виявляється в егоїстичному різновиді (на відміну від асертивного та альтруїстичного), коли продуцент висловл ення маніпулює свідомістю адресата задля досягнення власної мети. Мета маніпуляції викликати в адресата необхідне для маніпулятора ставлення до об 'єкта незалежно від бажання та інтересів самого адресата. Останній, зі свого боку, не пов инен розпізнати цю комунікативну настанову. Нині маніпуляцію розглядають як мистецтво керувати поведінкоюза допомогою цілеспрямованого впливу на психіку, свідомість та інстинкти людини, як духовне управління, як примус, інстр ументом якого є ірраціональні засоби. У процесі маніпуляції адресат не усвідомлює вплив, майже не має можливості критично аналізувати інформацію, визнає іiі морально прийнятною (Самборська 35), отже, маніпуляція має дестр уктивний характер, цей вплив шкодить особам, на яких спрямований.

Відкритий психологічний вплив у художній літературі відрізняється від маніпуляції в політичному дискурсі за параметрами моральності, усвідомленості, критичності та соціальної автономності. Письменник використовує високодуховні потреби й мотиви для формування поглядів у читача, зорієнтований на двобічну партнерську взаємодію, вибудовує підгрунтя для прийняття рішень адресата.

Вплив у художньому тексті асоціюють із регулятивністю, що «процес спіл кування < . .> організовує, оперуючи лінгвальними одиницями навмисного впли- 
ву та зображувальності як засобом керування пізнавально-естетичною діяльністю адресата, а потенційно в майбутньому - і його поведінкою у пр оцесі поза текстової комунікації» (Галаур 147). Під час ознайомлення з художнім текстом, у якому реалізується політичний дискурс, читач отримує завдання правильного тлумачення розгортання образів, послідовностей. Цю процедуру він здійснює за допомогою регулятивних мовних засобів, що стимулюють мовно-мисленнєву діяльність читача й стають основою для майбутнього моделювання концептів.

Регулятивні засоби функціюють у конкретній художній текстовій системі й створюють соціально-політичне тло. Регулятивними засобами зазвичай стають стилістично маркована лексика, тропи, стилістичні фігури, прийоми, інтертек стуальні елементи, ключові слова тощо. Регулятивні засоби експліцитні, вони чітко помітні на поверхневому рівні й змушують читача реагувати. Проаналізуємо найчіткіше окреслені регулятивні засоби в художньому політичному дискурсі.

Суспільно-політичною лексикою номінуємо особливу лексико-семантичну підсистему, яку становить «найбільш вживана частина суспільно-політичної тер мінології, назви державних, партійних та інших громадських організацій і закладів, соціальних інститутів, найменування соціальних реалій та явищ життя різних країн» (Снісаренко 139). Суспільно-політична лексика - це широкий багатоплановий корпус слів, різних за понятійною та функційною сфер ою, але об' єднаних із соціолінгвістичного погляду в один потік вербалізації подій, фено менів державного та громадського життя суспільства в динамічних процесах розвитку мови, в оцінювальних, критичних, дискусійних і зрештою актуальних положеннях, властивих певному соціуму в конкретну історичну добу. Орган ізація політичного простору того чи того суспільства детермінує обсяг та структуру суспільно-політичної лексики, у якій ословеснюються суспільно-політичні реалії. Якщо в державі спостережено суспільне та економічне будівництво, су спільно-політична лексика поповнюється новими словами. Ядром суспільнополітичної лексики постають суспільно-політичні терміни - різні за походженням номінативні одиниці, «спеціалізовані лексично (створені а бо запозичені тер міни), семантично (загальновживані слова, що отримали тер мінологічне зна чення) і фразеологічно (новостворені словосполучення номінативного характеру)» (Карабута 56). Загальним критерієм приналежності лексичної одиниці до категорії суспільно-політичної лексики є «поняттєво-смислова співвіднесеність із суспільно-політичною сферою» (Снісаренко 145).

Ознаками суспільно-політичної лексики є: відкритість (постійне поповнення одиницями інших лексичних розрядів), нечітка стильова належність (участь широких верств населення в політичному житті, громадській діяльності досить часто спр ичинює перехід цієї маркованоїлексики в загальновживану), соціальноідеологічна аксіологічність (загалом оцінка є основним складником конотації політичного тексту), реалізація значення в межах двох контекстів - лінгвального та екстралінгвального (декодування семантики з опорою на соціальні мотиви комунікантів, їхні системи цінностей, фонові знання тощо). Суспільно-політична лексика, найактивніше вживана в текстах сучасної української художньої л ітератури, містить лексико-семантичні групи слів - номенів фактів та явищ: 
1) національно-державного та національно-територіального устрою (держава, унітарна держава, незалежна держава, великодержава, супердержава, імперія, федерація, автономія), 2) державних перетворень (суверенітет, незалежність, самостійність, соборність, реформування, правова держава), 3) міжнар одних відносин, зовнішньої політики й дипломатичної практики (дестабілізація, євроінтеграція, інтегрування, роззброєння, озброєння, стабілізація, безвізовий режим, гуманітарна місія, еміграція, нейтралітет, протекиіонізм, спостережна місія, саміт, форум, біженець), 4) громадських рухів усередині держави (акиіі протесту, мітинг, народний контроль). Поширені найменування світоглядних понять, що відбивають інтереси, ідеали, настрої людей, суспільства загалом (nатріотизм, ментальність, солідарність, толерантність, шовінізм), суб' єктів політики за характером і способами діяльності, за партійною належністю чи пр ихильністю до певної ідеології (західник, лідер, опозиціонер, політв 'язень, правозахисник, сепаратист, націоналіст, бютівець, комуніст, радикал), політичних, філософських поглядів суб' єктів політики (геополітика, європеїзація, націоналізм, фашизм, неофашизм, нацизм, радикалізм). У сучасній художній літературі зафіксовано високий ступінь концентрації сленгової й колоквіальної лексики, здебільшого соціально-ідеологічно-оцінної. Ці слова пов' язані з політичними та громадськими рухами, політичними поглядами й особливо з таким параметром контексту, як ціннісні орієнтації суб'єктів суспільно-політичної комунікації (регулюиія, майданутий, правосєк, укроп, бандерлог, бандерштат, бандеризм, тітушки).

Евфемізми та дисфемізми є активними одиницями політичної мови й в иконують роль функційно-стилістичних синонімів.

Евфемізація є безперер вним процесом заміни деяких найменувань на інші, «пом' якшувальні», заснованим на постійній орієнтації на успішне спілкування. Роль евфемії в політичному дискурсі - нейтралізація істинного змісту суспільнополітичних найменувань, небажаних з етичних чи політичних причин: $A$ коли підійшли досвідчені (говорили, щзо ие російськігереушники), то саме й то ді почалася ота бісова гра, ми ї називали боулінгом: тепер уже нафаршировані ивяхами гранати вони кидали низом, котили по землі, як ото збивають кеглі пластмасовими кулями («Літературна Україна 2016»). Використовуючись для пр иховування або часткового вуалювання діяльності влади, армії, поліції, р о $3-$ відки та деяких інших структур, здатні до полярного трансформування змісту висловлення, а отже, програмування необхідного результату комунікативної взаємодії, евфемізми постають ідеологічними ключами, ефективними засобами формування суспільної свідомості.

Оскільки евфемізми приховують дійсність, вони є інструментами впливу, можливо, навіть маніпулятивного. Такі одиниці зручні для політичного дискурсу, у художньому та політичному ж як більш продуктивні зафіксовані дисфемізми. Останні, на відміну від евфемізмів, мають знижене стилістичне забарвлення, висловлюють негативну оцінку експліцитно, а не імпліцитно: Це небезпечний московський собацюра, котрий понівечив не однулюдську долю; Ми взяли курс на Європу, до Європейського Союзу, відірвавшись від кайданів Путіна і від його 
імперського мракобісся, щуо нависло над нашою Батьківщиною («Літер атурна Україна 2019»).

Сучасна українська літер атура відбиває активний процес дисфемізації мови. Більшість сфер нашого життя, на жаль, зазнали вульгаризації, мовної агресії. Письменники досить часто демонструють невимушений психологічний стан мовця, що спонукає його діяти наперекір суспільним нормам і заборонам, використовуючи тактики дискримінації. Художня література найчастіше репрез ентує суспільно-політичні дисфемізми, які маркують національну належність та політичні погляди. Автори художніх творів можуть показувати, що дисфемізми $\epsilon$ наслідком дотримання мовної моди для створення іміджу «своєї», простої, людини, звичайного робітника чи воїна, що розмовляє зрозумілою для всіх мовою, навіть із лайливими виразами.

На тлі фразеологізованих суспільно-політичних термінів особливо вирізняються суспільно-політичні метафори, які, на думку Л. Климанської, можна вважати «ресурсому фор муванні громадської думки, і не тільки в процесі в ибудови іміджу кандидата на ту чи ту посаду на політичному Олімпі, а й у ств ор енні іміджу соціальній проблемі» (Климанська 20). Метафора дає змогу репрезентувати щось не до кінця усвідомлене за допомогою зрозумілої форми, отже, виконує інформаційну функцію. Крім того, важливою є і її прагматична функція, оскільки цей троп є потужним інструментом трансформації наявної у свідо мості реципієнта політичної картини світу, заохочення його до конкр етних політичних дій, фор мування в нього необхідного емоційного стану. Сучасний художній політичний дискурс характеризується високим ступенем метафоричності, серед різних моделей метафоризації в художній політичній мові превалюють метафори стану країни, війни: Чи загину під час стрілянини на вулиці, бо випадково потраплю на лінію вогню (Дашвар Люко).

Активне вживання суспільно-політичної лексики в художній мові сприяє її переосмисленню й розвитку нових значень, що постають унаслідок не лише метафоричних, але й метонімічних перенесень. Останні вказують на особливе суб' єктивно-оцінне ставлення автора до явища, події: Приӥхав Сорос, каже, що Украӥна у світі має дуже поганурепутацію, а до чого тут Україна, нам же їі підмінили, а куди ж ми дивилися, так нам і треба! - я не помітив, що говорю сам з собою (Костенко Л.).

Найпопулярнішою стилістичною фігурою в художньому політичному ди скурсі варто вважати антитезу, яка вибудовується за допомогою підкресленого протиставлення протилежних понять, явищ, думок, образів та почуттів. В осн ову антитези художнього політичного дискурсу покладено антонімічну пар у суспільно-політичних понять, які фор мують бінарні образи. Висловлення пр от иріччя в бінар ній структурі виявляє високий ступінь сугестивності, оскільки від ношення протилежності легко сприймаються та обробляються людською свідо містю. Антитеза сучасного художнього політичного дискурсу залучає ідеологічно орієнтовані слова, що відбивають поляризацію між групами «свій / чужий», «позитивний / негативний», «правильний / хибний»: Мовляв, то погані украӥн ці- фашисти, бандерівці та русофоби-розпочали громадянську війну проти 
хороших украӥнців, а хороші українці завжди були за Росію. Хоромі українці братній нам народ, і циих хороших українців треба рятувати (Кідрук Макс). Прийом антитези допомагає «підкреслити парадоксальність ситуації, яка скл алася» (Моркотун 40).

Категорія впливу в художньому політичному дискур сі реалізується в су бкатегорії регулятивного впливу. Ї̈ маркерами постають регулятивні засоби, за допомогою яких письменник установлює тісний контакт із читачем. Останній легко помічає їх у тексті, через них намагається зрозуміти намір автора. Пер спективами дослідження можуть стати комунікативні стратегії, реалізовані ко нкретними регулятивними мовними засобами.

\section{Література}

1. Безугла Л. Р. Вербалізація імпліцитних смислів у німецькомовному діалогічному дискурсі: монографія. Харків: ХНУ ім. В. Н. Каразіна, 2007. 332 с.

2. Галаур С. П. Регулятивність та ії місце в системі категорій художнього тексту. Лінгвістичні дослідження. 2018. Вип. 48. С. 145-152.

3. Гребінь Н. В. Зміст маніпуляції як різновиду прихованого психологічного впливу. Проблеми сучасної психології. 2013. Вип. 21. С. 80-93.

4. Карабута О. Сучасна суспільно-політична лексика: семантико-структурний аспект. Науковий вісник ХДУ. Серія: Лінгвістика, 2013. Вип. 19. С. 54-57.

5. Климанська Л. Потенціал метафори в політиці вирішення соціальних проблем. Науковий вісник Ужгородського університету. Серія: Політологія, Соціологія, Філософія. 2010. Вип. 14. С. 18-24.

6. Моркотун С. Відтворення експресивності образних засобів при перекладі текстів політичного дискурсу. Синопсис: текст, контекст, медіа. 2017. № 3(19). С. 39-47.

7. Самборська О. В. Соціально-психологічні механізми переконуючого впливу: дис. ... канд. психол. наук: 19.00.05. Київ, 1997. 190 с.

8. Снісаренко Я. Суспільно-політична лексика як специфічна лексична категорія. Гуманітарна освіта у технічних вищих навчальних закладах. 2012. Вип. 26. С. 136-149.

\section{References}

1. Bezuhla, Liliia. Verbalizatsiia implitsytnykh smysliv u nimetskomovnomu dialohichnomu dyskursi (Verbalization of implicit meanings in German dialogic discourse). Kharkiv: KhNU im. V. N. Karazina, 2007. Print.

2. Halaur, Svitlana. "Rehuliatyvnist ta yii mistse v systemi katehorii khudozhnoho tekstu (Regulativity and its place in the system of categories of artistic text)". Linhvistychni doslidzhennia (Linguistic researches). 48 (2008): 145-152. Print.

3. Hrebin, Nataliia. "Zmist manipuliatsii yak riznovydu prykhovanoho psykholohichnoho vplyvu (The content of manipulation as a kind of hidden psychological influence)". Problemy suchasnoi psykholohii (Problems of modern psychology). 21 (2013): 80-93. Print.

4. Karabuta, Olena. "Suchasna suspilno-politychna leksyka: semantyko-strukturnyi aspekt (Modern socio-political vocabulary: semantic-structural aspect)". Naukovyi visnyk Khersonskoho derzhavnoho universytetu. Seriia: Linhvistyka (Scientific Bulletin of Kherson State University. Series: Linguistics). 19 (2013): 54-57. Print.

5. Klymanska, Larysa. "Potentsial metafory $\mathrm{v}$ politytsi vyrishennia sotsialnykh problem (The potential of metaphor in the policy of solving social problems)". Naukovyi visnyk Uzhhorodskoho universytetu. Seriia: Politolohiia, Sotsiolohiia, Filosofiia (Scientific Bulletin of Uzhhorod University. Series: Political Science, Sociology, Philosophy). 14 (2010): 18-24. Print. 
6. Morkotun, Serhii. "Vidtvorennia ekspresyvnosti obraznykh zasobiv pry perekladi tekstiv politychnoho dyskursu (The reproduction of figurative means expressivity in the process of translation the political discourse texts)". Synopsys: tekst, kontekst, media (Synopsis: text, context, media). 3 (19) (2017): 39-47. Print.

7. Samborska, Olenaю. Sotsialno-psykholohichni mekhanizmy perekonuiuchoho vplyvu (Social and psychological mechanism of persuasive influence). Diss. Shevchenko University of Kyiv, 1997. Print.

8. Snisarenko, Yana. "Suspilno-politychna leksyka yak spetsyfichna leksychna katehoriia (Social and political vocabulary as a specific lexical category)". Humanitarna osvita u tekhnichnykh vyshchykh navchalnykh zakladakh (Humanitarian education in technical institutions of higher education). 26 (2012): 136-149. Print.

\section{Список джерел}

1. Дашвар Люко. Ініціація. Харків: Клуб Сімейного Дозвілля, 2018. 416 с.

2. Кідрук Макс. Небратні. Харків: Клуб Сімейного Дозвілля, 2015. 304 с.

3. Костенко Л. Записки українського самашедшого. Київ: А-БА-БА-ГА-ЛА-МА-ГА, 2010. $416 \mathrm{c}$.

4. Літературна Україна. № 48. 15 грудня 2016. С. 8-9.

5. Літературна Україна. № 31-32. 31 серпня 2019. С. 16-17.

\section{List of Sources}

1. Dashvar, Lyuko. Initsiatsiya (Initiation). Kharkiv: Klub Simeynoho Dozvillya, 2018. Print.

2. Kidruk, Maks. Nebratni (Not fraternal). Kharkiv: Klub Simeynoho Dozvillya, 2015. Print.

3. Kostenko, Lina. Zapysky ukrayins 'koho samashedshoho (Notes of the crazy Ukrainian). Kyiv: A-BA-BA-HA-LA-MA-HA, 2010. Print.

4. Literaturna Ukraina (Literary Ukraine), 48 (2016): 8-9. Print.

5. Literaturna Ukraina (Literary Ukraine), 31-32 (2019): 16-17. Print.

\section{POLITICAL DISCOURSE IN FICTION AND ITS REGULATIVITY INFLUENCE}

\section{Svitlana Halaur}

Department of General Linguistics and Foreign Languages, National University "Yuri Kondratyuk Poltava Polytechnic", Poltava, Ukraine.

\section{Iryna Yakubenko}

Department of General Linguistics and Foreign Languages, National University "Yuri Kondratyuk Poltava Polytechnic", Poltava, Ukraine.

\section{Abstract}

Background: The concept of discourse as a complex communicative phenomenon dominates in various fields of modern linguistics. Nowadays, the problem of political discourse that is intensively gaining its priority in the life of society and even manifests itself in fiction is important.

Purpose: The aim of the paper is to analyze regulativity as a special influence in political discourse in fiction.

Results: Regulativity is a subcategory of the category of influence and actively manifests itself in political discourse in fiction. The regulativity tools facilitate correct interpretation of political images by stimulating the language and thought activity of the reader and becoming the basis for future modeling of concepts. Regulativity means are always explicit and represented in the analyzed texts of fiction in sociopolitical vocabulary, dysphemisms, metaphor, and antithesis.

Sociopolitical vocabulary verbalizes sociopolitical realities in the political discourse in fiction. This vocabulary most often nominates phenomena and facts of the national-state and nationalterritorial system, state transformations, foreign policy and diplomatic practice, and social movements throughout the country. The presence of dysphemisms in the literary text indicates the process of language aggression in all spheres of human life. Sociopolitical metaphors are perhaps the 
most powerful resource in shaping public opinion. Antithesis as a simple way of expressing contradictions shows a high degree of suggestibility.

Discussion: The category of influence in political discourse in fiction requires a more detailed study of the writer-addressee's communicative strategies represented by regulativity means.

Keywords: discourse, political discourse in fiction, category of influence, regulativity, regulativity means of political discourse in fiction.

Vitae. Svitlana Halaur is a Candidate of Philology, Associate Professor, Associate Professor of Department of General Linguistics and Foreign Languages at National University "Yuri Kondratyuk Poltava Polytechnic". Her areas of research interests include functional linguistics, text linguistics, and linguistic pragmatics.

Correspondence: svitlana.galaur@ gmail.com

Vitae. Iryna Yakubenko is a Candidate of Philology, Senior lecturer of Department of General Linguistics and Foreign Languages at National University "Yuri Kondratyuk Poltava Polytechnic". Her areas of research interests include German syntax, text linguistics, communicative linguistics, linguistic stylistics, linguopragmatics, psycholinguistics.

Correspondence: iryna.yakubenko1@gmail.com

Надійшла до редакціії 23 вересня 2020 року. Рекомендована до друку 15 жовтня 2020 року. 